\title{
MICROBIOLOGICAL ACTIVITY DURING THE COMPOSTING OF WASTES FROM BROILER PRODUCTIVE CHAIN
}

\section{Francieli H. Bernardi' ${ }^{1}$, Mônica S. S. de M. Costa ${ }^{2 *}$, Luiz A. de M. Costa ${ }^{1}$, Felippe M. Damaceno ${ }^{1}$, Maico Chiarelotto ${ }^{1}$}

\author{
${ }^{2 *}$ Corresponding author. Research Group on Water Resources and Environmental Sanitation, Western Parana State University/ \\ Cascavel - PR, Brazil. E-mail: monicasarollisilva@gmail.com
}

\section{KEYWORDS}

basal respiration, alkaline phosphatase, $\mathrm{pH}, \boldsymbol{\beta}$-glucosidase, cellulase, urease.

\begin{abstract}
The quality of the carbon used as bulking agent in the composting process directly affects the dynamics of the waste degradation, which is governed by an active and diversified microbiota. The monitoring of the basal respiration and enzymatic activities during the composting of broiler agro-industrial wastes with different carbon sources as bulking agents was the aim of this study. The microbiological activities were more intense in the thermophilic phase of the process. The dynamics of the enzymatic activities were affected by the different carbon sources used as bulking agent in the composition of the windrows. When the milled sugarcane bagasse was used as carbon source, the windrow presented the highest amount of $\mathrm{P}$ in its constitution and presented, in the evaluation averages, a greater intensity of the alkaline phosphatase enzyme ( $842 \mu \mathrm{g} \mathrm{g}^{-1} \mathrm{~h}^{-1} \mathrm{p}$-nitrophenol compost); the highest intensities of $\beta$-glucosidase and cellulase enzymes were observed when fresh and ground napier grass was used as the main source of carbon $\left(6.1 \mu \mathrm{mol} \mathrm{g}^{-1} \mathrm{~h}^{-1}\right.$ p-nitrophenol compost and $35.2 \mu \mathrm{mol} \mathrm{g}^{-1} 16 \mathrm{~h}^{-1}$ glucose compost, respectively); the highest intensity of the urease enzyme was also observed in the windrow where napier grass was used as the main carbon source and bulking agent $\left(205,890 \mu \mathrm{mol} \mathrm{g}{ }^{-1} 2 \mathrm{~h}^{-1} \mathrm{~N}-\mathrm{NH}^{4+}\right.$ compost). It can be concluded that napier grass when used as the main source of carbon and bulking agent in the composting of the wastes from broiler chicken production chain promotes greater intensity of most of the enzymatic activities of interest. The enzymatic activity of urease presented the highest values due to the high nitrogen content of the composted wastes.
\end{abstract}

\section{INTRODUCTION}

According to the Annual report of the Brazilian Association of Animal Proteins (ABPA, 2017), in the year of 2016, the national production of chicken meat was 12.9 million tons being only behind the United States in the world ranking of chicken meat production. Of the total produced, 66\% were absorbed by the domestic market and $34 \%$ were exported, guaranteeing for Brazil the first place in the world ranking of chicken meat exports. In the national scenario, the South region stands out in the slaughter of chicken, representing $63.63 \%$ of the national slaughter, being $33.46 \%$ represented by the state of Paraná. Since 2000, Paraná has emerged as the largest domestic producer of poultry meat in 2016 as the most exporting state, with $35.85 \%$ of the national total (ABPA, 2017). The expressiveness of the numbers also reveals the problem of the daily generation of highly polluting residues (solids, liquids and atmospheres), especially those generated in the period before the fattening phase (reproductive poultry husbandry and hatchery wastes) and during the slaughter and industrialization phase of the chicken meat (floatation sludge and sausage casings, respectively) (Bernardi, 2011). In the last years, the most acceptable destiny to these wastes have been the composting process. Several composting plants were built up nearby the production centers, generally cooperatives, and they have worked in the outdoor system of windrows. However, as these wastes are rich in nitrogen the most important hindrance is the amount and quality of the carbon source to be added to the wastes aiming to reach an ideal or close to ideal $\mathrm{C}: \mathrm{N}$ ratio, for the process to take place properly.

Research Group on Water Resources and Environmental Sanitation, Western Parana State University, Agricultural Engineering Graduate Program, Rua Universitária, 2069, Jardim Universitário, 85.819-110, Cascavel - PR, Brazil.

${ }^{1}$ Western Parana State University/ Cascavel - PR, Brazil. 
Costa et al. (2017) concluded that, with exception of sawdust, all the other evaluated carbon sources (cotton fiber, urban tree trimming, sugarcane bagasse or Napier grass) provided good alternatives regarding the composting area optimization as the composting time did not exceeded 90 days. Moreover, the evaluated carbon sources, mainly the cotton fiber wastes, also allowed the nutrients conservation in the final compost avoiding environmental impacts and adding commercial and agronomic value. Therefore, it is possible to infer that the quality of the carbon source used as bulking agent in the composting process directly affects the degradation dynamic of the wastes which is governed by an active and diversified microbiota.

Some indexes are used to monitor the microbiological activity during the composting process. Among them is the measurement of the basal respiration rate $\left(\mathrm{CO}_{2}\right.$ production) which indicates the total metabolic activity of all microbiological processes that occur during the organic material degradation. This analysis has been used as a measure to monitor the microbiological activity and the organic material degradation (Barrena et al., 2014; Nikaeen et al., 2015).

Meanwhile, the microorganisms cannot directly metabolize the insoluble particles of organic materials. Instead, they produce extracellular hydrolytic enzymes to depolymerize the larger fragments into smaller compounds that are water soluble (Kong et al., 2018). The evolution of enzymatic activity during composting can be used as an adequate indicator of the state and evolution of organic matter (Villar et al., 2016) and can be used to characterize a reliable index of compost stability (Jurado et al., 2014).

Important enzymes which are involved in the composting process are: cellulase which depolymerize cellulose; $\beta$-glucosidases which are involved in the carbon cycle through the hydrolysis of glucosides; proteases and ureases which take part in nitrogen mineralization; and phosphatases and arylsulphatases which release phosphate and sulphates groups from organic compounds (Vargas-García et al., 2010). As a consequence, specific enzymatic activities can provide a characterization of the composting process, both in terms of the organic waste transformation rate as of the stabilized final products (Nikaeen et al., 2015), with emphasis on the availability of plant nutrients (Lakshmi et al., 2014). Thus, the monitoring of the intensity of the enzymatic activity can contribute to decision making along with other process control parameters, especially with regard to the availability of nutrients in the inorganic form.

The objective of this study was to provide an evaluation of the microbiological activity during the composting process of the productive chain of broiler chicken and different carbon sources.

\section{MATERIAL AND METHODS}

The experiment was conducted in the Experimental Center of Agricultural Engineering (NEEA) belonging to the Western Parana State University (UNIOESTE). NEEA is located at BR $467, \mathrm{~km} \mathrm{16}$, municipality of Cascavel in the following coordinates: $24^{\circ} 48^{\prime} \mathrm{S}$ and $53^{\circ} 26^{\prime} \mathrm{W}$ and average altitude of $760 \mathrm{~m}$.

Different regionally wastes were used in the composting process as carbon sources: cotton fiber wastes, urban tree trimmings, sawdust, sugarcane bagasse and
Napier grass. The treatments were formed in function of the carbon source added to the wastes from the broiler productive chain, as following:

$\mathrm{T}_{1}$ : cotton fiber wastes

$\mathrm{T}_{2}$ : urban tree trimmings

$\mathrm{T}_{3}$ : sawdust

$\mathrm{T}_{4}$ : milled sugarcane bagasse

$\mathrm{T}_{5}$ : ground Napier grass

The other wastes from the broiler productive chain which composed the composting piles were: reproductive poultry litter, hatchery waste, flotation sludge, sausage casings and left-over charcoal. The $\mathrm{C}: \mathrm{N}$ ratio was maintained around 30:1 in all treatments, for this the amount of carbon sources varied, without however, exceed $50 \%$ of the total weight of the windrow. Further details on the composting process conducted in this research can be found in Costa et al. (2017).

Windrow and ambient temperature were monitored daily in six points each windrow chosen randomly using a mercury thermometer, at a depth of $25 \mathrm{~cm}$.

The $\mathrm{pH}$ was determined in a solution prepared with the composting material sample in distilled water at a ratio of 1:5 (w/v) (Tedesco et al., 1995) and the values were measured using a bench $\mathrm{pH}$ meter (TECNAL, model TEC3MP).

The analysis of basal respiration was determined according to Garcia-Gomez et al. (2003), with some modifications, in samples collected biweekly, soon after each turn over, throughout the composting process. Briefly, fresh samples, equivalent to $8 \mathrm{~g}$, were incubated (BOD) in approximately $250 \mathrm{~mL}$ plastic vials at $26^{\circ} \mathrm{C}$ for seven days. The $\mathrm{CO}_{2}$ produced was adsorbed into $10 \mathrm{~mL}$ in a $\mathrm{NaOH} 2 \mathrm{M}$ solution placed inside the vial containing the compost sample. Three replicates of blank samples were also conducted.

The evolution of $\mathrm{C}-\mathrm{CO}_{2}$ was determined by titration of the $\mathrm{NaOH}$ solution with $\mathrm{HCl} 2 \mathrm{M}$ in an excess of $\mathrm{BaCl}_{2}$ $(1 \%)$. The basal respiration rate was expressed as $\mathrm{mg} \mathrm{C}$ $\mathrm{CO}_{2} \mathrm{~kg}^{-1}$ day $^{-1}$, according to the equation below:

$$
\text { Basal Respiration }=\frac{\frac{((V b-V s) * 2 * 12)}{\text { Weight of the sample }(D M)}}{7}
$$

In which:

$$
\begin{aligned}
& \text { Vb: Volume spent on blank titration } \\
& \text { Vs: Volume spent on sample titration } \\
& \text { 2: Molarity of Hydrochloric Acid } \\
& \text { 7: Days of incubation }
\end{aligned}
$$

The analyses of enzymatic activities were assessed in six samplings according to temperature evolution during the composting process for all treatments, as presented below:

Sampling 1: In the assembly of the experiment;

Sampling 2: Final of the mesophilic and beginning of the thermophilic phase;

Sampling 3: Thermophilic phase;

Sampling 4: Thermophilic phase; 
Sampling 5: Final of the thermophilic phase and beginning of the mesophilic phase;

Sampling 6: Final of the composting process.

The analyses of the enzymatic activities (acid phosphatase, total cellulase, $\beta$-Glucosidase and urease) were performed in water extracts prepared with frozen samples. The samples were not defrosted before weighing. The methodologies used were based on modifications proposed by Cunha-Queda (1999), adapted from methods proposed by Hermann \& Shann (1993) and Tabatabai (1982).

The enzymatic extract was prepared stirring $10 \mathrm{~g}$ of fresh sample with $200 \mathrm{~mL}$ of distilled water during 5 minutes. Aliquots of the supernatant were used for the enzymatic activity analyses which were determined in duplicate with one blank to each sample.

All absorbance readings were performed on a spectrophotometer (FEMTO, model 700 Plus). The results of the enzymatic activities were expressed in $\mu \mathrm{mol}$ of the product formed per gram of dry matter in time $\left(\mu \mathrm{mol} \mathrm{g} \mathrm{g}^{-1} \mathrm{~h}^{-1}\right)$.

\section{RESULTS AND DISCUSSION}

\section{Thermal profile of the windrows}

In Table 1, it is possible to observe the duration of the thermophilic phase besides other control parameters of the process related to the thermal profile of the windrows.

TABLE 1. Information on the thermophilic phase of the composting process.

\begin{tabular}{|c|c|c|c|c|c|}
\hline Parameter & $\mathrm{T}_{1}$ & $\mathrm{~T}_{2}$ & $\mathrm{~T}_{3}$ & $\mathrm{~T}_{4}$ & $\mathrm{~T}_{5}$ \\
\hline $\begin{array}{l}\text { Duration of the thermophilic } \\
\text { phase }^{\text {a }} \text { (days) }\end{array}$ & 56 & 56 & 33 & 31 & 56 \\
\hline Maximun temperature $\left({ }^{\circ} \mathrm{C}\right)$ & 67 & 67 & 61 & 60 & 69 \\
\hline Maximun temperature (day) & $9^{\circ}$ & $13^{\circ}$ & $26^{\circ}$ & $31^{\circ}$ & $13^{\circ}$ \\
\hline Temperature $\geq 55^{\circ} \mathrm{C}$ (days) & 29 & 28 & 3 & 7 & 37 \\
\hline Composting time & 84 & 91 & 154 & 91 & 91 \\
\hline $\mathrm{EXI}^{\mathrm{b}}$ & 95051 & 101669 & 71574 & 59938 & 115183 \\
\hline EXI/ Composting time & 1132 & 1137 & 468 & 659 & 1265 \\
\hline
\end{tabular}

a Thermophilic phase: temperature $>40^{\circ} \mathrm{C}$.

${ }^{b}$ EXI: Exothermic accumulation: quadratic sum of the daily difference between the average temperature of the windrow and the ambient temperature during the stabilization phase.

The thermal profile of the composting windrows is directly related to the microbial activity, what is, the exothermic metabolism of the microorganisms can be measured by the inside temperature of the windrows (Sánchez et al., 2017; Jain et al., 2018). By the thermal profile of the composting windrows it is possible to identify the four characteristic phases of the process: mesophilic, thermophilic, cooling and maturity (Sánchez et al., 2017). In Figure 1, it is possible to observe the behavior of the temperature in the different windrows (treatments).

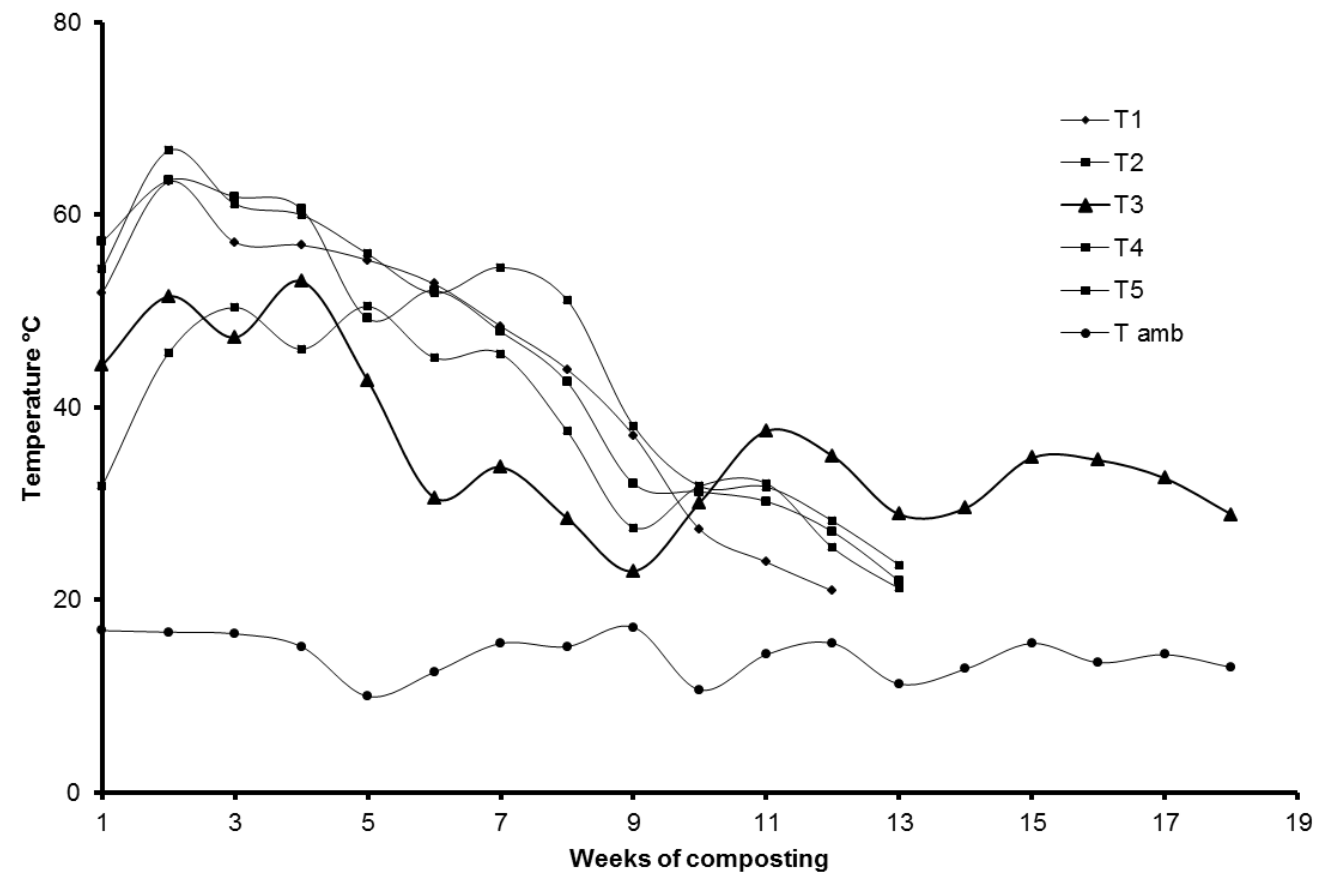

FIGURE 1. Temperature behavior in the windrows (treatments) and in the ambient during the composting process. 
By the data presented on Table 1, it is possible to observe that the carbon source imposed differentiated conditions to microbiota which reflected in different thermal profiles.

It is initially observed that the maximum temperature in each situation imposed by the carbon sources was reached in the following order: $\mathrm{T}_{1}<\mathrm{T}_{2}=\mathrm{T}_{5}<\mathrm{T}_{3}<\mathrm{T}_{4}$.

Concerning the sanitization of the composting process, Gavilanes-Terán et al. (2016) comment about the importance to maintain at least for 15 days, temperatures of $55{ }^{\circ} \mathrm{C}$ to ensure the maximum pathogens and weeds reduction, according to the European Commission (2014) requirements. It can be observed that the most labile carbon sources (cotton, tree pruning and Napier grass) were efficient in guaranteeing times much higher than indicated, and that the sources of sawdust and sugarcane bagasse did not reach the imposed limit, which can be explained by the granulometry and recalcitrance of the carbon sources. While the sawdust presents fine granulometry, which makes it difficult to aerate and therefore limits the temperature, the coarse granulometry of the sugarcane bagasse may have promoted the heat dispersion, reducing the windrows temperature (Costa et al., 2017). Still, the sawdust represents a recalcitrant carbon source that hinders microbial attack, and therefore the temperature, as indicative of microbial activity, is lower.

The high intensity of the thermophilic phase in the treatments (windrows) $T_{1}, T_{2}$ and $T_{5}$, besides reflecting in a longer time in temperatures equal to or higher than $55^{\circ} \mathrm{C}$ was also reflected in greater exothermic accumulation, a fact also observed by Jara-Samaniego et al. (2017).

\section{Basal respiration}

As the microbial activity is reflected in the temperature behavior, a direct relationship between temperature and basal respiration is expected, which is actually observed once the intensity of basal respiration (Figure 2) is higher in the thermophilic phase of composting (Figure 1). This behavior during the thermophilic phase can be attributed to the presence of easily degradable materials that stimulate the microbial community (Jara-Samaniego et al., 2017).

Figure 2 shows a differentiated behavior of basal respiration as a function of the carbon sources evaluated. It can be clearly seen that the sources of sugarcane bagasse and Napier grass promoted more pronounced basal respiration, and that the use of sawdust resulted in lower basal respiration than the other two, but more prolonged than the other sources (cotton fiber wastes and urban tree trimmings). The explanation for this behavior is different for each carbon source used. While the basal respiration intensity at $\mathrm{T}_{5}$ (Napier grass) is related to the thermal profile of the windrow (Figure 1 and Table 3), i.e., higher values of basal respiration (microbial activity) were reflected in higher temperatures, treatments $T_{3}$ and $T_{4}$ present behaviors that do not relate to temperature. The explanation again refers to the granulometry and the quality of carbon sources. Sugarcane bagasse presents lower lignin contents (10.4\%) than sawdust (27.3\%), so it is more easily degraded by the microbiota, which should be reflected in higher temperatures. However, its granulometry favors heat dispersion, referred to as natural convection loss due to excessively high porosity by Chang et al. (2017). Meanwhile, the behavior of the basal respiration intensity when the carbon source is sawdust is related to the fact that it contains a significant amount of lignin, a recalcitrant organic polymer that inhibits microbial access to cellulose and hemicellulose (Khan et al., 2014). 


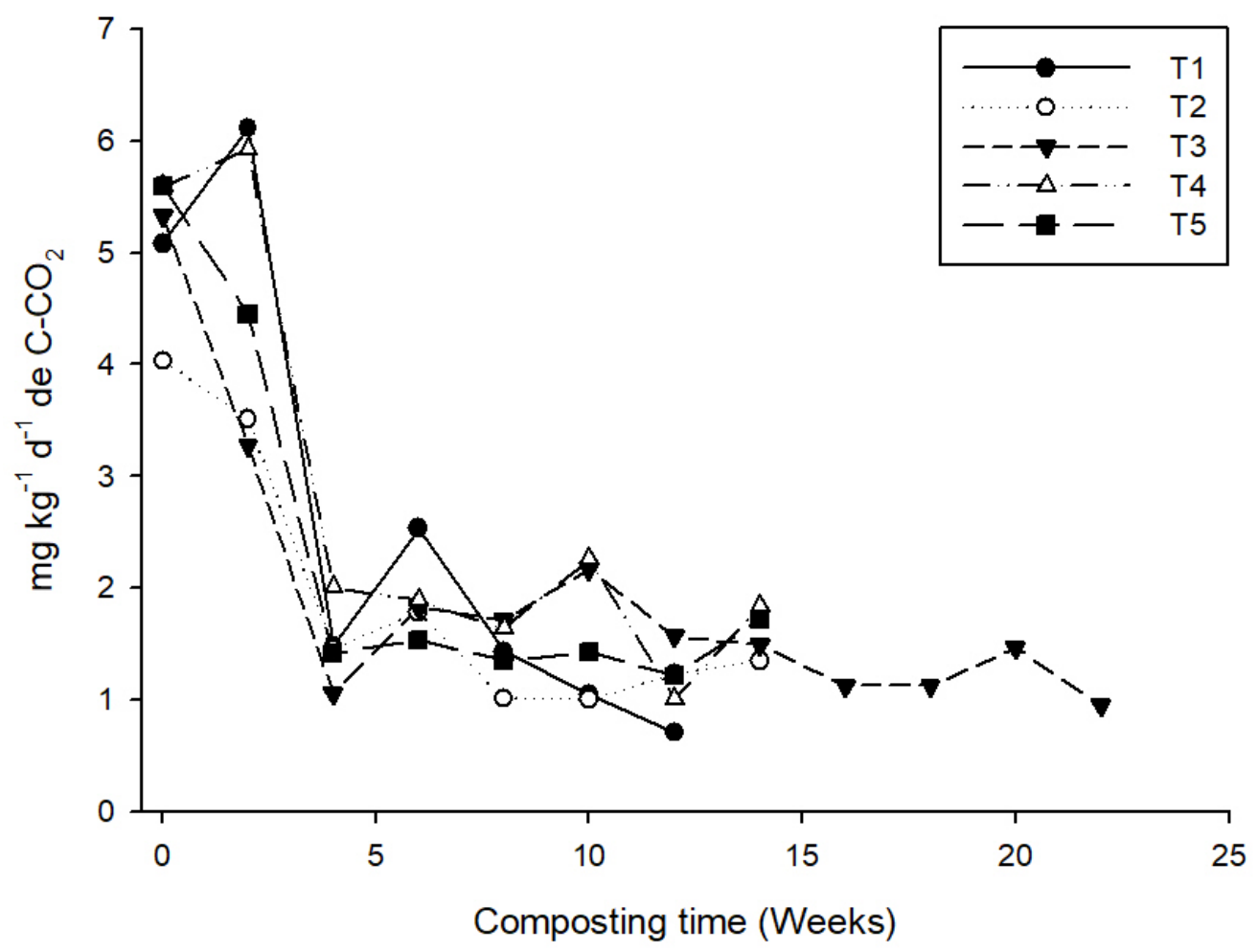

FIGURE 2. Behavior of the basal respiration during the composting process.

\section{Enzymatic activities during the composting process}

The highest intensity of the enzymatic activities evaluated occurred during the thermophilic phase of the composting process, for all treatments. Other authors working with enzymatic activity during the composting process observed the same behavior, enzymatic activity increase in the thermophilic phase and reduction in the healing phase (Jurado et al, 2014).

\section{Alkaline phosphatase activity}

Phosphatase activity is involved in the hydrolysis of organic phosphorus to different inorganic forms that plants can metabolize (Awasthi et al., 2015). Figure 3 shows the behavior of alkaline phosphatase activity during the composting process. Due to the $\mathrm{pH}$ values presented in the alkalinity range for all treatments (Figure 4), alkaline phosphatase activity was predominant, a fact also observed by Lakshmi et al. (2014).

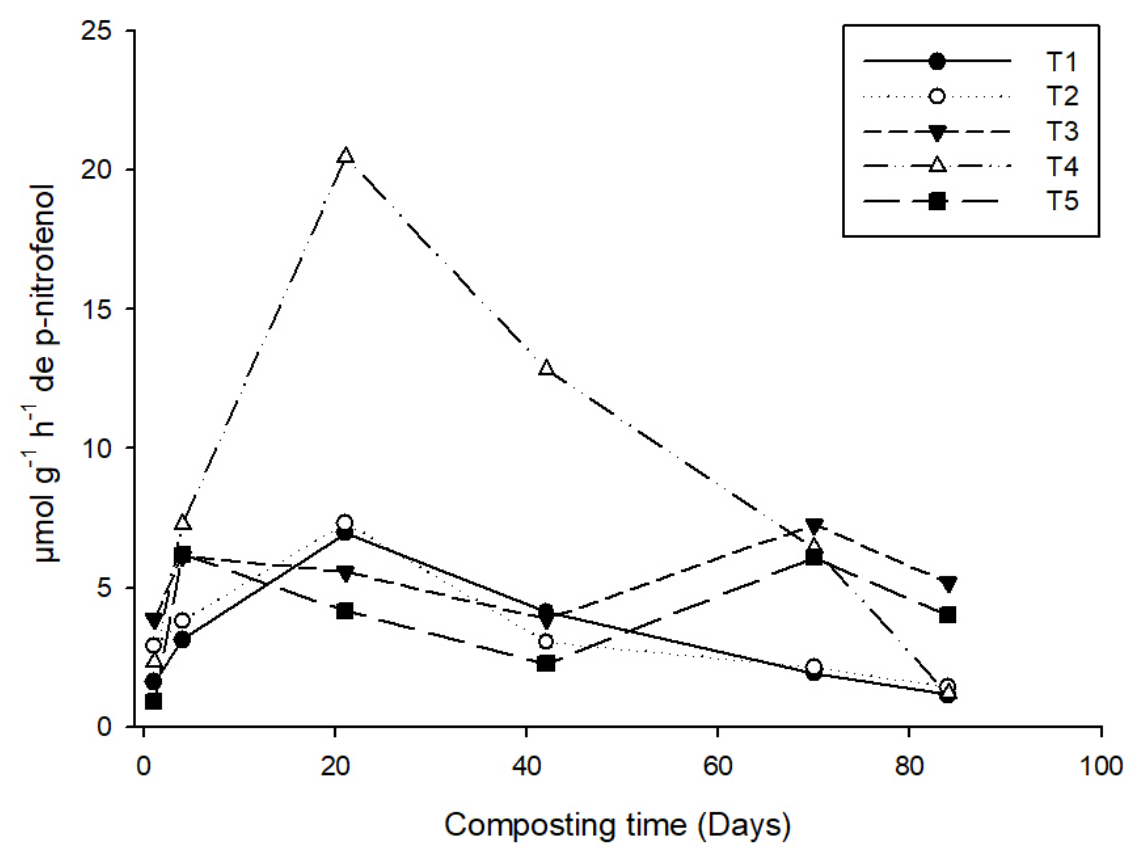

FIGURE 3. Behavior of the enzymatic activity Phosphatase Alkaline during the composting process. 


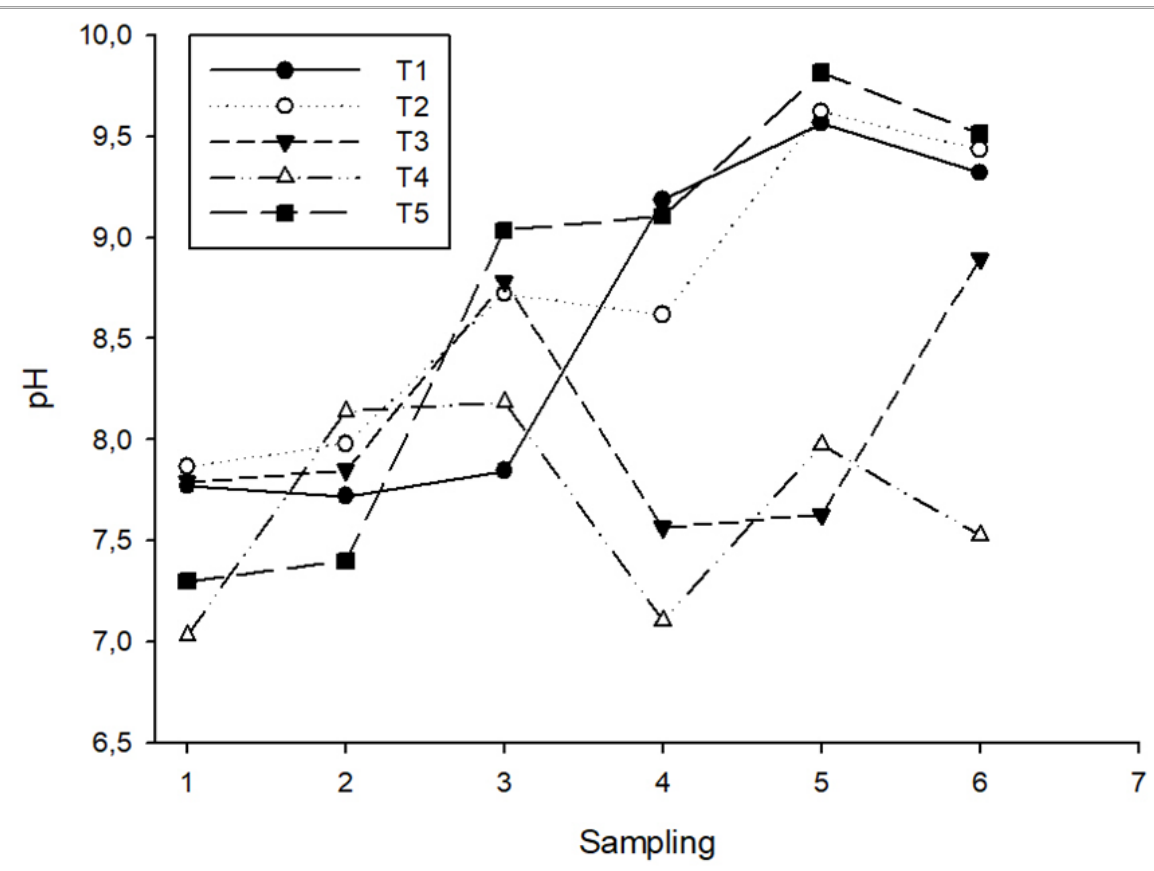

FIGURE 4. Behavior of the $\mathrm{pH}$ during the composting process.

The highest activity of alkaline phosphatase (Figure 3) was observed in the $T_{4}$ treatment, the same treatment presented the highest initial amount of total phosphorus $(0.78 \mathrm{~kg} \mathrm{P})$ among the treatments. Considering the results obtained by Costa et al. (2017) for the same treatment configurations, $\mathrm{T}_{4}$ also presented the highest losses of $\mathrm{P}$ during the composting process $(40.3 \%)$. The organic $\mathrm{P}$ is an element of difficult mobility, therefore, it can be inferred that these losses are related to the inorganic form of the element, which corroborates Figure 3 results, since the greater activity of phosphatase in $\mathrm{T}_{4}$ produced greater amount of orthophosphate (inorganic form of $\mathrm{P}$ ), which being soluble in water was lost by leaching during the moisture correction.

The decrease in the intensity of phosphatase activity in the composting final phase can be attributed to changes in the interaction matrix between humic substances and enzymes during the process (Cunha-Queda et al., 2007).

\section{$\beta$-Glucosidase activity}

Figure 5 shows the behavior of the $\beta$-Glucosidase enzymatic activity during the composting process of the various carbon sources evaluated.

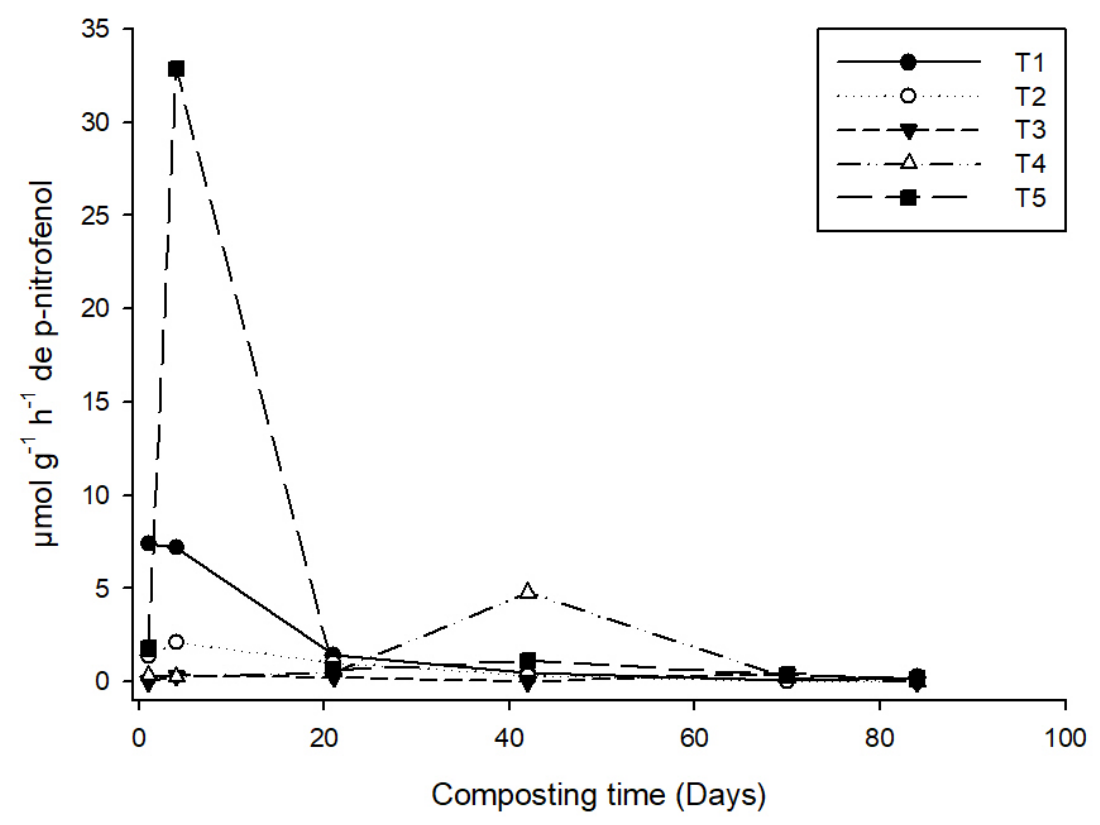

FIGURE 5. Behavior of the $\beta$-Glucosidase enzymatic activity during the composting process. 
Cellulose is the most abundant carbohydrate in plant biomass and, because it is available, it can be used as a carbon source in the composting process of agroindustrial waste in order to balance the C:N ratio of the windrows to approximately 25 (Oliveira et al., 2017). All microorganisms capable of degrading cellulose do, by secreting more or less complex enzymes. Initially, the fibers fragmentation of the cellulosic material exposing the cellulose occurs. Subsequently, the release of endoglucanase, exoglucanase and cellobiase with free and non-reducing ends, provides the enzymatic hydrolysis of cellulose into oligosaccharides. Finally, by the excretion of $\beta$-glucosidase, oligosaccharides are hydrolyzed into glucose monomers, which are assimilable by the microorganisms involved in composting. For this reason, $\beta$-glucosidase is the limiting enzyme of the cellulose degradation rate (Li et al., 2013).

The highest value of the $\beta$-Glucosidase enzymatic activity was verified in the $\mathrm{T}_{5}$ treatment, between the end of the mesophilic phase and the beginning of the thermophilic phase. Therefore, it is possible to infer that among the five different carbon sources used in each windrow (cotton fiber waste, urban tree trimmings, sawdust, milled sugarcane bagasse and ground Napier grass), the cellulose of the treatment $\mathrm{T}_{5}$ (ground Napier grass) is the most labile form of carbon (Figure 4). According to Jurado et al. (2014), $\beta$-glucosidase is one of the main enzymes that regulate the carbon cycle and its activity is an indication of the presence of organic matter easily usable by microorganisms as energy source.
Cotton fiber wastes $\left(\mathrm{T}_{1}\right)$ and urban tree trimmings $\left(\mathrm{T}_{2}\right)$ presented similar enzymatic activities of $\beta$ Glucosidase from the beginning of the composting process until the beginning of the thermophilic phase, however, this activity was more intense in $T_{1}$ than in $T_{2}$. This behavior may be related to the fact that $T_{1}$ had $61.7 \mathrm{~kg}$ of cotton fiber, and $\mathrm{T}_{2}$ had $55.4 \mathrm{~kg}$ of urban tree trimmings (Costa et al., 2017). In addition, the cellulose from the cotton fiber waste is more easily degraded than the fibers of the urban tree trimmings, due to the greater $\beta$ Glucosidase activity observed in the first one (Figure 4).

Sugarcane bagasse $\left(\mathrm{T}_{4}\right)$, unlike Napier grass $\left(\mathrm{T}_{5}\right)$, cotton fiber $\left(\mathrm{T}_{1}\right)$ and urban tree trimmings $\left(\mathrm{T}_{2}\right)$, showed higher enzymatic activity of $\beta$-Glucosidase in the thermophilic phase. The activity of the $\beta$-Glucosidase enzyme was very discrete in all phases of the composting process in the windrow containing sawdust $\left(\mathrm{T}_{3}-70.4 \mathrm{~kg}\right.$ of cellulose coming from sawdust). The low presence of such enzyme evidences the recalcitrance of the sawdust cellulose (Costa et al., 2017), which comes from wood (Leconte et al., 2009).

Cellulase activity

Figure 6 shows the behavior of the cellulase enzymatic activity during the composting process of the various carbon sources evaluated. Cellulases are enzymatic complexes composed of endoglucanases, exoglucanases and $\beta$-Glucosidase (Santos et al., 2017). Microorganisms such as bacteria, fungi and actinomycetes produce enzymes such as cellulase to catalyze the hydrolysis of cellulose, transforming it into smaller molecules of sugars. Zeng et al. (2010) and Wang et al. (2014) inoculated these microorganisms during the composting process to accelerate the stabilization of organic materials.

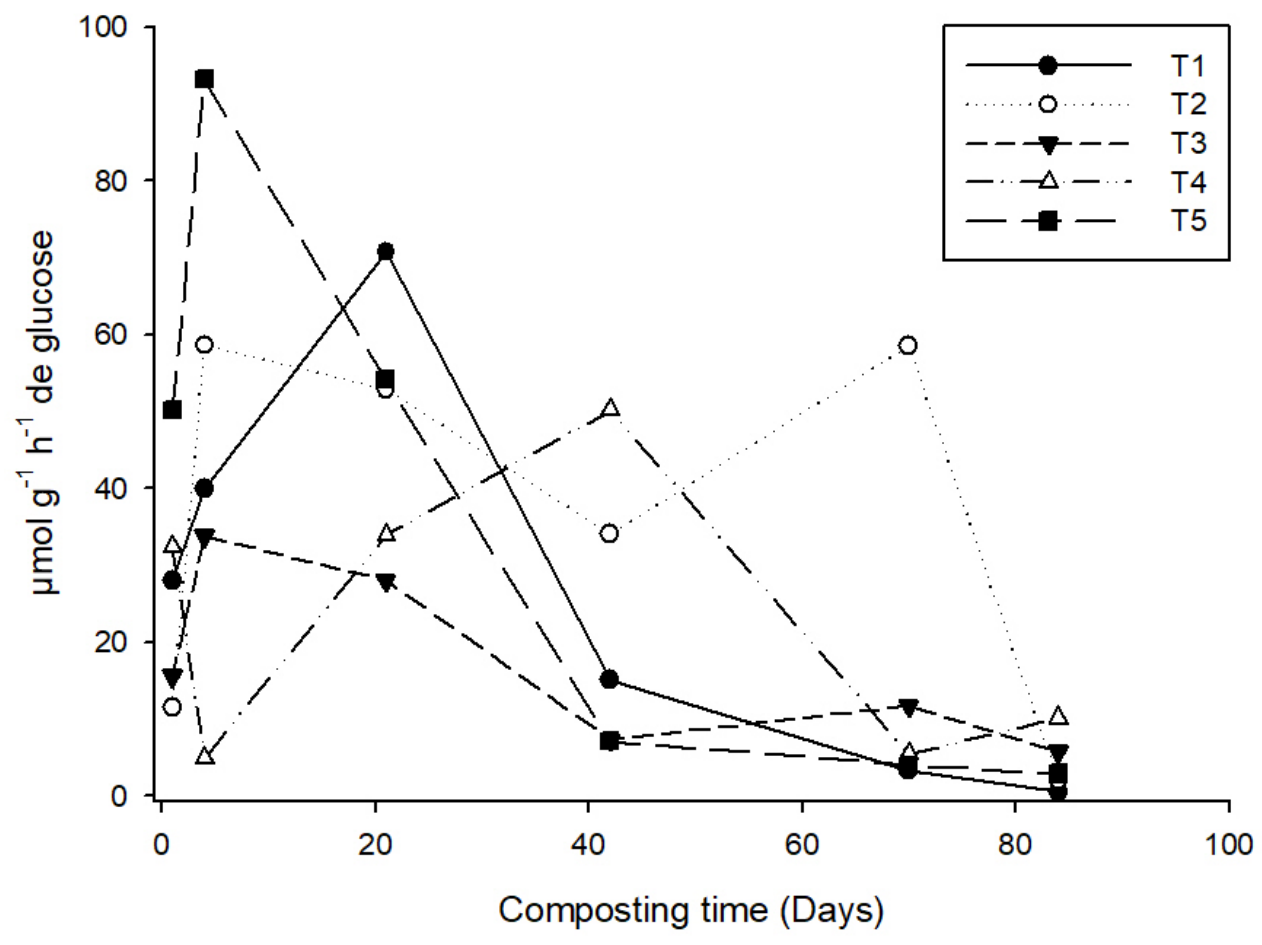

FIGURE 6. Behavior of the cellulase enzymatic activity during the composting process. 
Napier grass $\left(T_{5}\right)$ certainly influenced the enzymatic activity of cellulase, since $T_{5}$ presented the highest cellulase peak in less composting time, reinforcing the inference that such a carbon source is more labile than the others. Behavior similar to $T_{5}$ was observed by $T_{1}$ (cotton fiber wastes), but the enzymatic activity of cellulase was a little less intense and occurred mainly in the phase of active degradation of the windrow (Figure 6). The treatments showed the highest initial amounts of cellulose (163.9 kg and $109.2 \mathrm{~kg}$, respectively for $\mathrm{T}_{1}$ and $\mathrm{T}_{5}$ ) and the highest cellulose reductions in the experiment (92 and 90\%, respectively for $\mathrm{T}_{1}$ and $\mathrm{T}_{5}$ ) (Costa et al., 2017).

The lower enzymatic activities of cellulase and $\beta$ glucosidase were observed in the $T_{3}$ treatment, which has the highest amount of lignin, a more recalcitrant carbon, more resistant to biological decomposition, because of its chemical structure (Khan et al., 2014). Lignin confers sufficient limitation to retard, or even completely prevent, microbial action on the material, interfering with hydrolysis and blocking the access of cellulases to cellulose.

\section{Urease activity}

Figure 7 shows the behavior of the enzymatic activity of urease during the composting process of the various carbon sources evaluated. The enzymatic activity of urease catalyzes the transformation of urea into $\mathrm{CO}_{2}$ and ammonium, thus, low intensity of urease activity during the composting process results in low ammonia volatilization (Kong et al., 2018), that is, lower losses of $\mathrm{N}$ during the process.

The ammonization occurs when oxygen is present (as in the composting process) in practically all ecosystems and is performed by practically all microorganisms that are involved in the decomposition of organic matter. Ammonia can be easily verified when the $\mathrm{pH}$ of the compost windrow increases during early composting phases (Sánchez et al., 2017).

Figure 7 shows that when milled sugarcane bagasse was used as a carbon source in the composition of windrow $4\left(\mathrm{~T}_{4}\right)$, the urease activity presented the lowest intensity among the other sources. By the results of $\mathrm{N}$ losses (\%) during the process, according to Costa et al. (2017), the windrow in which the milled sugarcane bagasse $\left(\mathrm{T}_{4}\right)$ was used presented the lower $\mathrm{N}$ losses ( $\mathrm{p}$ $<0.050$ ) when compared to the other treatments. Therefore, it is inferred that bacteria that convert organic $\mathrm{N}$ to ammonium, which can be more easily lost, did not find ideal conditions for this procedure. Also related to the relationship between the intensity of the urease enzymatic activity and the $\mathrm{N}$ losses, it is observed that the highest losses occurred in $\mathrm{T}_{3}$ and $\mathrm{T}_{5}$, in which also it is observed a greater enzymatic activity.

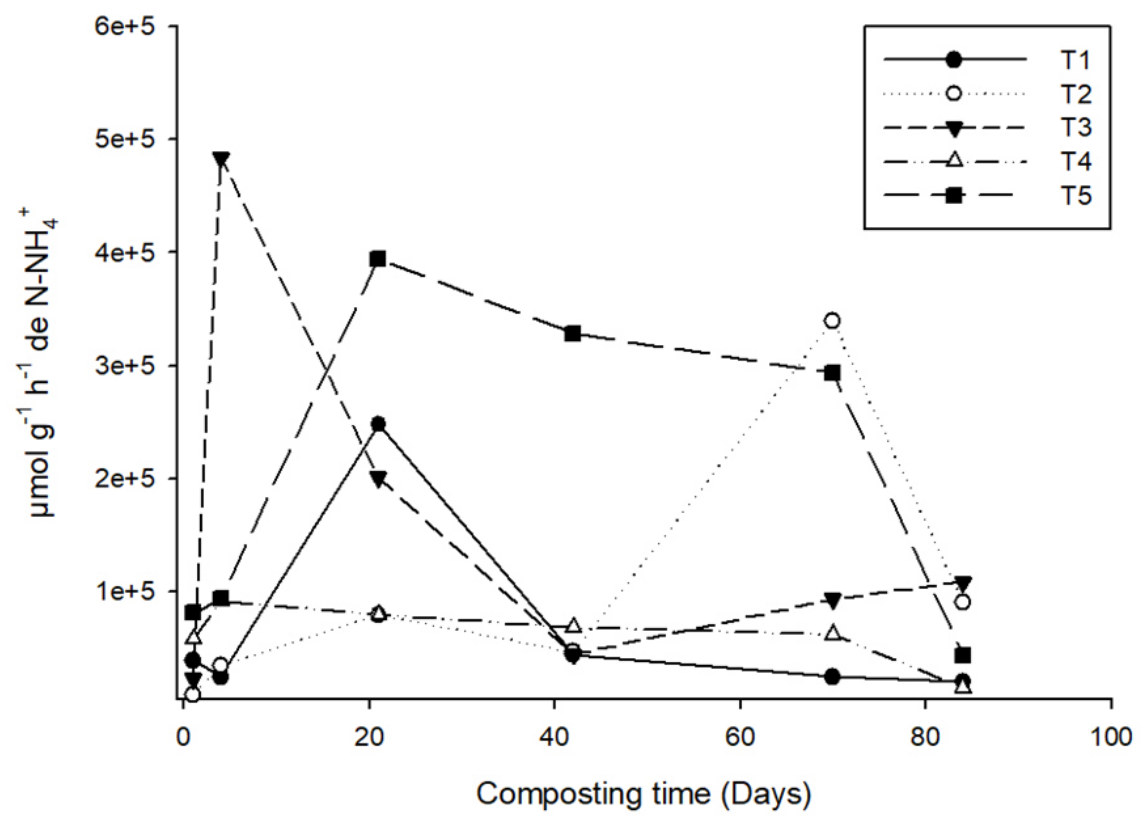

FIGURE 7. Behavior of the urease enzymatic activity during the composting process.

\section{CONCLUSIONS}

The main carbon source used as a bulking agent in the composition of the windrows in which the wastes from the broiler production chain were composted affects the microbiota of the process. The Napier grass promoted greater intensity of the $\beta$-glucosidase, cellulase and urease enzymes. The intensity of basal respiration and enzymatic activities is greater in the thermophilic phase of the process. The urease enzymatic activity is the most pronounced when the composting of agroindustrial wastes from the broiler production chain as a function of the large amount of nitrogen from these residues.

\section{ACKNOWLEDGEMENTS}

The authors thank to FUNDAÇÃO ARAUCÁRIA (Process n. 300932/2015-4, Agreement 156/2014) for the financial support and to the Coordination for the Improvement of Higher Education Personnel - CAPES for the first author's Doctorate scholarship. 


\section{REFERENCES}

ABPA - Associação Brasileira de Proteína Animal (2017) Relatório anual de 2017. ABPA.

Awasthi MK, Pandey AK, Bundela PS, Khan J (2015) Cocomposting of organic fraction of municipal solid waste mixed with different bulking waste: Characterization of physicochemical parameters and microbial enzymatic dynamic. Bioresource Technology 182:200-207.

Barrena R, Font X, Gabarrell X, Sánchez A (2014) Home composting versus industrial composting: influence of composting system on compost quality with focus on compost stability. Waste Management 34:1109-16.

Bernardi FH (2015) Materiais lignocelulósicos na compostagem de resíduos da agroindústria do frango de corte. Tese de Doutorado, Universidade Estadual do Oeste do Paraná.

Chang R, Guo Q, Chen Q, Bernal MP, Wang W, Li Y (2017) Effect of initial material bulk density and easilydegraded organic matter content on temperature changes during composting of cucumber stalk. Journal of Environmental Science. Available: https://doi.org/10.1016/j.jes.2017.10.004

Costa MSSM, Bernardi FH, Costa LAM, Pereira DC, Lorin HEF, Rozatti MAT, Carneiro LJ (2017) Composting as a cleaner strategy to broiler agro-industrial wastes: Selecting carbon source to optimize the process and improve the quality of the final compost. Journal of Cleaner Production 142:2084-2092.

Cunha-Queda ACF (1999) dinâmica do azoto durante a compostagem de materiais biológicos putrescíveis. $\mathrm{PhD}$ Thesis, Universidade Tecnica de Lisboa Instituto Superior de Agronomia.

Cunha-Queda AC, Ribeiro HM, Ramos A, Cabral F (2007) Study of biochemical and microbiological parameters during composting of pine and eucalyptus bark. Bioresource Technology 98:3213-3220.

European Commission (2014) End-of-waste Criteria for Biodegradable Waste Subjected to Biological Treatment (Compost \& Digestate): Technical Proposals. Available in: http://ipts.jrc.ec.europa.eu/publications/pub.cfm?id=6869.

Accessed: Mar 24, 2018.

Garcia-Gomez A, Roig A, Bernal MP (2003) Composting of the solid fraction of olive mill wastewater with olive leaves: organic matter degradation and biological activity. Bioresource Technology 86:59-64.

Gavilanes-Terán I, Jara-Samaniego J, Idrovo-Novillo J, Bustamante MA, Moral R, Paredes C (2016) Windrow composting as horticultural waste management strategy A case study in Ecuador. Waste Management 48:127-134.

Hermann RF, Shann JF (1993) Enzymes activities as indicators of municipal solid waste compost maturity. Compost Science and Utilization 4:54-63.
Jain MS, Jambhulkar R, Kalamdhad AS (2018) Biochar amendment for batch composting of nitrogen rich organic waste: Effect on degradation kinetics, composting physics and nutritional properties. Bioresource Technology 253:204-213.

Jara-Samaniego J, Perez-Murcia MD, Bustamante MA, Perez-Espinosa A, Paredes C. Lopez M, Lopez-Lluch DB, Gavilanes-Teran I, Moral R (2017) Composting as sustainable strategy for municipal solid waste management in the Chimborazo Region, Ecuador: Suitability of the obtained composts for seedling production. Journal of Cleaner Production 141:1349-1358.

Jurado MM, Suárez-Estrella F, Vargas-García MC, López MJ, López-González JA, Moreno J (2014) Increasing native microbiota in lignocellulosic waste composting: Effects on process efficiency and final product maturity. Process Biochemistry 49:1958-1969.

Khan N, Clark I, Sánchez-Monedero MA, Shea S, Meier S, Bolan N (2014) Maturity indices in co-composting of chicken manure and sawdust with biochar. Bioresource Technology 168:245-251.

Kong Z, Wang X, Liu Q, Li T, Chen X, Chai L, Liu D, Shen Q (2018) Evolution of various fractions during the windrow composting of chicken manure with rice chaff. Journal of Environmental Management 207:366-377.

Lakshmi CSR, Rao PC, Sreelatha T, Madhavi M, Padmaja G, Sireesha A (2014) Changes in enzyme activities during vermicomposting and normal composting of vegetable market waste. Agricultural Science Digest 34(2):107-110.

Leconte MC, Mazzarino MJ, Satti P, Iglesias MC, Lao F (2009) Co-composting rice hulls and/or sawdust with poultry manure in NE Argentina. Waste Management 29(9):2446-2453.

Li H, Xu X, Chen H, Zhang Y, Xu J, Wang J, Lu X (2013) Molecular analyses of the functional microbial community in composting by PCR-DGGE targeting the genes of the bglucosidase. Bioresource Technology 134:51-58.

Nikaeen M, Nafez AH, Bina B, Nabavi BF, Hassanzade A (2015) Respiration and enzymatic activities as indicators of stabilization of sewage sludge composting. Waste Management 39:104-110.

Oliveira LSBL, Oliveira DSBL, Bezerra BS, Pereira BS, Battistelle RAG (2017) Environmental analysis of organic waste treatment focusing on composting scenarios. Journal of Cleaner Production 155:229-237.

Sánchez OJ, Ospina DA, Montoya S (2017) Compost supplementation with nutrients and microorganisms in composting process. Waste Management 69:136-153.

Santos DA, Oliveira MM, Curvelo AAS, Fonseca LP, Porto ALM (2017) Hydrolysis of cellulose from sugarcane bagasse by cellulases from marine-derived fungi strains. International Biodeterioration \& Biodegradation 121:66-78. 
Tabatabai MA (1982) Soil Enzymes. In: Page AL, Miller RH, Keeney DR (eds) Methods of Soil Analysis, ASA, SSSA, Publisher, p 903-947.

Tedesco MJ, Gianello C, Bissani CA, Bohnen H, Wolkweiss SJ (1995) Análise de solo, plantas e outros materiais. Porto alegre, Universidade Federal do Rio Grande do Sul, 2 ed. 174 p.

Vargas-García MC, Suárez-Estrella F, López MJ, Moreno J (2010) Microbial population dynamics and enzyme activities in composting processes with different starting materials. Waste Management 30:771-778.
Villar I, Alves D, Garrido J, Mato S (2016) Evolution of microbial dynamics during the maturation phase of the composting of different types of waste. Waste Management 54:83-92.

Wang C, Tu Q, Dong D, Strong PJ, Wang H, Sun B (2014) Spectroscopic evidence for biochar amendment promoting humic acid synthesis and intensifying humification during composting. Journal of Hazardous Materials 280:409-416.

Zeng G, Yu M, Chen Y, Huang D, Zhang J, Huang H, Jiang R, Yu Z (2010) Effect of inoculation with Phanerochaete chrysosporium at various time points on enzyme activities during agricultural waste composting. Bioresource Technology 101:222-227. 